\title{
Effect of Dietary Supplementation of Blood Meal and Additional Magnesium on Carnosine and Anserine Concentrations of Pig Muscles
}

\author{
Se Won Park, Chan Ho Kim, Jong Woong Kim, Hye Seong Shin, In Kee Paik, and Dong Yong Kil* \\ Department of Animal Science and Technology, Chung-Ang University, Anseong 456-756, Korea
}

\begin{abstract}
The objective of this study was to investigate the effect of dietary supplementation of blood meal as a source of L-histidine, and the addition of magnesium $(\mathrm{Mg})$ as a catalyst of carnosine synthetase for the carnosine and anserine concentrations of pig muscles (longissimus dorsi, LD and vastus intermedius, VI). A total of twenty-four pigs with an average body weight of $60.2 \pm 4.2 \mathrm{~kg}$ were randomly allotted to one of three dietary treatments (eight replicates), during $56 \mathrm{~d}$ of the feeding trial. Dietary treatments included: (1) Basal: basal diet; (2) BM: $95 \%$ basal diet $+5 \%$ blood meal; and (3) BM+Mg: $94.8 \%$ basal diet $+5 \%$ blood meal $+0.2 \% \mathrm{MgO}(60 \% \mathrm{Mg})$. Results indicated that drip loss in the LD was less $(p<0.05)$ for meat with $\mathrm{BM}+\mathrm{Mg}$ treatment than that with Basal treatment, but the values for BM treatment did not differ from those of the other two treatment groups. The concentrations of carnosine in the $\mathrm{LD}$ were increased by $10.0 \%$ in both $\mathrm{BM}$ and $\mathrm{BM}+\mathrm{Mg}$ treatment groups over the Basal treatment group (significance not verified). The concentrations of carnosine and anserine in the VI were not affected by the dietary treatments. Inclusion of additional $\mathrm{Mg}$ in diets had no effect on carnosine and anserine concentrations in the LD and VI. In conclusion, dietary supplementation of blood meal could be a potential method of fortifying the pork with carnosine. Inclusion of additional $\mathrm{Mg}$ in the diets containing blood meal had no benefit on carnosine and anserine depositions in pig muscles.
\end{abstract}

Key words: anserine, carnosine, Longissimus dorsi, pigs, Vastus intermedius

\section{Introduction}

Carnosine ( $\beta$-alanyl-L-histidine) is a cytoplasmic dipeptide present in various animal tissues such as brain, skeletal muscle, and heart (Boldyrev and Severin, 1990) and is synthesized from L-histidine and $\beta$-alanine by carnosine synthetase with $\mathrm{Mg}$ as a catalyst (Kalyankar and Meister, 1959). Anserine is a methylated form of carnosine (Boldyrev and Severin, 1990). It has been reported that carnosine and anserine have beneficial roles such as antioxidants, antiglycation molecules, and anti-aging agents (Bogardus and Boissonneault, 2000; Nagasawa et al., 2001), and therefore, they have been considered as functional bioactive compounds for human consumption (Guiotto et al., 2005).

There have been many efforts to produce animal products fortified with carnosine and anserine, particularly by a dietary means. It has been reported that dietary supple-

\footnotetext{
*Corresponding author: Dong Yong Kil, Department of Animal Science and Technology, Chung-Ang University, Anseong 456756, Korea. Tel: 82-31-670-3028, Fax: 82-31-676-2196, E-mail: dongyong@cau.ac.kr
}

mentation of blood meal high in L-histidine that is a direct source of carnosine synthesis increased carnosine and anserine concentrations in chicken breast (Auh et al., 2010; Park et al., 2013). However, there has been limited information about the pork by feeding the diets containing blood meal to pigs. In addition, $\mathrm{Mg}$ is an essential cofactor of carnosine synthetase, and therefore, inclusion of additional $\mathrm{Mg}$ in the diets containing blood meal may be effective to promote carnosine and anserine synthesis in animal products. This hypothesis has been tested in chickens previously (Namgung et al., 2010; Park et al., 2013), but it has not been verified in pigs.

The objective of the current experiment, therefore, was to determine the effect of dietary supplementation of blood meal with or without additional $\mathrm{Mg}$ on the concentrations of carnosine and anserine in pig muscles (longissimus dorsi, LD and vastus intermedius, VI).

\section{Materials and Methods}

\section{Experimental design and diets}

A total of 24 pigs [(Landrace $\times$ Yorkshire $) \times$ Duroc] were used in this experiment. Average initial body weight of 
pigs was $60.2 \pm 4.2 \mathrm{~kg}$. All pigs were randomly allotted to 1 of 3 dietary treatments and each treatment had 8 replicated pigs ( 4 barrows and 4 gilts). Three dietary treatments included: (1) basal diet (Basal), (2) 95\% basal diet $+5 \%$ blood meal (BM), and (3) $94.8 \%$ basal diet $+5 \%$ blood meal $+0.2 \% \mathrm{MgO}(60 \% \mathrm{Mg}$; $\mathrm{BM}+\mathrm{Mg})$. All diets were formulated to meet or exceed the estimated requirements for all nutrients (NRC, 1998). Energy concentrations were similar across all 3 dietary treatments. The nutrient compositions of experimental diets were presented in Table 1. A commercial-type blood meal was purchased from a local company (Arirang BNS, Korea) and analyzed for lysine $(1.48 \%)$, methionine $(2.32 \%)$, threonine $(4.33 \%)$, valine $(6.20 \%)$, and histidine $(6.33 \%)$. The diets and water were supplied to pigs as ad libitum basis for $56 \mathrm{~d}$ to reach average market body weight of approximately $105 \mathrm{~kg}$. All animal protocol for this experiment was reviewed and approved by the Institutional Animal Care and Use Committee at Chung-Ang University.

\section{Sample preparation}

On the last day of the experiment, all pigs were fasted for $12 \mathrm{~h}$ and were then transported to a commercial abattoir near the experimental station. After arrival, pigs were kept in holding pens for 1 to $3 \mathrm{~h}$, and then slaughtered by electrical stunning, lifted off the floor, and exsanguinated. Carcasses were eviscerated, split, and placed in a chilling room at $5{ }^{\circ} \mathrm{C}$ for $12 \mathrm{~h}$. The samples for the $\mathrm{LD}$ between $9^{\text {th }}$ and $13^{\text {th }}$ rib and the VI were collected from all pigs and were kept in an ice box during transporting to the laboratory. The LD and VI was frozen at $-60^{\circ} \mathrm{C}$ before the analyses of nutrients, carnosine, and anserine. The $\mathrm{pH}$, drip loss, and meat color in the LD were determined at $38 \mathrm{~h}$ after slaughter.

\section{Sample analysis}

Amino acid compositions in 3 diets and blood meal were determined by the method of Baker et al. (2011). Nutrient concentrations in diets and muscles were analyzed by AOAC methods (AOAC, 1990). The drip loss was measured according to the method of Honikel (1998). In short, a $4 \mathrm{~cm}$ thick slice of the LD (approximately $100 \mathrm{~g}$ ) were trimmed, placed in a plastic container, and suspended from a fish hook for $24 \mathrm{~h}$ at $4^{\circ} \mathrm{C}$. Drip loss was calculated by comparing the final and initial weight of the LD. The $\mathrm{pH}$ of the LD was measured by a pH meter (Model HI99163, Hanna Instruments, Romania). Meat color for CIE L* (lightness), a* (redness), and $\mathrm{b}^{*}$ (yellowness) of the LD was measured by a Minolta chromameter (Model CR-400,
Table 1. Formula and composition of experimental diets

\begin{tabular}{|c|c|c|c|}
\hline & \multicolumn{3}{|c|}{ Dietary treatments ${ }^{\mathrm{a}}$} \\
\hline & Basal & $\mathrm{BM}$ & $\mathrm{BM}+\mathrm{Mg}$ \\
\hline \multicolumn{4}{|l|}{ Ingredient, \% } \\
\hline Corn & 37.70 & 35.69 & 35.49 \\
\hline Wheat & 17.00 & 16.15 & 16.15 \\
\hline Soybean meal & 11.10 & 10.55 & 10.55 \\
\hline DDGS $^{b}$ & 10.00 & 9.50 & 9.50 \\
\hline Lupin kernel & 7.00 & 6.65 & 6.65 \\
\hline Blood meal & 0.00 & 5.00 & 5.00 \\
\hline Tallow & 4.00 & 3.80 & 3.80 \\
\hline Tapioca & 3.15 & 2.99 & 2.99 \\
\hline Molasses & 2.50 & 2.38 & 2.38 \\
\hline Rapeseed meal & 2.00 & 1.90 & 1.90 \\
\hline Limestone & 1.31 & 1.31 & 1.31 \\
\hline Palm kernel meal & 1.00 & 0.95 & 0.95 \\
\hline Rice bran & 0.85 & 0.81 & 0.81 \\
\hline Corn gluten meal & 0.81 & 0.77 & 0.77 \\
\hline Salt & 0.40 & 0.38 & 0.38 \\
\hline Wheat bran (domestic) & 0.30 & 0.29 & 0.29 \\
\hline L-Lysine-HCl-78\% & 0.28 & 0.28 & 0.28 \\
\hline Sugar & 0.15 & 0.15 & 0.15 \\
\hline L-Threonine-98\% & 0.05 & 0.05 & 0.05 \\
\hline Phytase & 0.05 & 0.05 & 0.05 \\
\hline NSP enzyme & 0.05 & 0.05 & 0.05 \\
\hline $\mathrm{MgO}$ & - & - & 0.20 \\
\hline Vitamin premix ${ }^{\mathrm{c}}$ & 0.15 & 0.15 & 0.15 \\
\hline Mineral premix ${ }^{\mathrm{d}}$ & 0.15 & 0.15 & 0.15 \\
\hline Total & 100.00 & 100.00 & 100.00 \\
\hline \multicolumn{4}{|c|}{ Energy and Nutrient composition ${ }^{\mathrm{e}}$} \\
\hline $\mathrm{ME}, \mathrm{kcal} / \mathrm{kg}$ & 3,350 & 3,331 & 3,331 \\
\hline Crude protein, $\%$ & 15.97 & 20.23 & 21.29 \\
\hline Crude fat, $\%$ & 7.39 & 7.67 & 7.26 \\
\hline Crude ash, \% & 5.96 & 6.02 & 6.11 \\
\hline Lysine, $\%$ & 1.76 & 1.50 & 1.51 \\
\hline Methionine, \% & 2.73 & 2.24 & 2.33 \\
\hline Threonine, $\%$ & 3.23 & 3.46 & 3.52 \\
\hline Valine, $\%$ & 1.50 & 1.50 & 1.42 \\
\hline Histidine, $\%$ & 4.37 & 5.92 & 5.54 \\
\hline $\mathrm{Ca}, \%$ & 0.62 & 0.62 & 0.62 \\
\hline $\mathrm{Mg}, \%$ & 0.16 & 0.17 & 0.28 \\
\hline
\end{tabular}

${ }^{a}$ Basal, the basal diets; BM, 95.0\% Basal $+5.0 \%$ blood meal; BM+ $\mathrm{Mg}, 94.8 \%$ Basal +5.0 blood meal $+0.2 \% \mathrm{MgO}$

${ }^{\mathrm{b}}$ Corn Distillers Dried grains with Solubles

'Provided per kilogram of the complete diet: vitamin A (from vitamin $\mathrm{A}$ acetate), 9,000 IU; vitamin $\mathrm{D}_{3}, 1,800 \mathrm{IU}$; vitamin $\mathrm{E}$ (from DL- $\alpha$-tocopheryl acetate), $25 \mathrm{IU}$; vitamin $\mathrm{K}_{3}, 2 \mathrm{mg}$; vitamin $\mathrm{B}_{1}$, $2 \mathrm{mg}$; vitamin $\mathrm{B}_{2}, 5 \mathrm{mg}$; vitamin $\mathrm{B}_{6}, 3 \mathrm{mg}$; vitamin $\mathrm{B}_{12}, 20 \mathrm{mg}$; calcium pantothenate, $15 \mathrm{mg}$; folic acid, $0.5 \mathrm{mg}$; biotin, $0.1 \mathrm{mg}$; niacin, $24 \mathrm{mg}$; pyridoxine, $2 \mathrm{mg}$; ethoxquine, $6.6 \mathrm{mg}$

${ }^{\mathrm{d}}$ Provided per kilogram of the complete diet: $\mathrm{Fe}\left(\right.$ as $\mathrm{FeSO}_{4} \cdot 7 \mathrm{H}_{2} \mathrm{O}$ ), $66.67 \mathrm{mg} ; \mathrm{Zn}$ (as $\mathrm{ZnSO}_{4} \cdot \mathrm{H}_{2} \mathrm{O}$ ), $36.67 \mathrm{mg} ; \mathrm{Mn}$ (as $\mathrm{MnSO}_{4} \cdot \mathrm{H}_{2} \mathrm{O}$ ), $34.4 \mathrm{mg}$; $\mathrm{Cu}$ (as $\mathrm{CuSO}_{4} \cdot 5 \mathrm{H}_{2} \mathrm{O}$ ), $66.67 \mathrm{mg}$, $\mathrm{Se}\left(\right.$ as $\mathrm{Na}_{2} \mathrm{SeO}_{3}$ ), 0.12 $\mathrm{mg} ; \mathrm{I}\left(\right.$ as $\left.\mathrm{Ca}\left(\mathrm{IO}_{3}\right)_{2} \cdot \mathrm{H}_{2} \mathrm{O}\right), 0.7 \mathrm{mg}$

${ }^{\mathrm{e}}$ Analyzed values for all nutrients except for ME and $\mathrm{Ca}$ (NRC, 1998) 
Minolta Co. Ltd., Japan). The color measurements were performed 3 times with different surfaces of the samples and the average values were calculated.

The concentrations of carnosine and anserine in the LD and VI were analyzed by the methods of Aristoy and Toldra (2004). Briefly, approximately $10 \mathrm{~g}$ frozen samples of the LD and VI were freeze-dried to a constant weight and finely ground. The ground samples were mixed with 24 $\mathrm{mL}$ of distilled water in a centrifuge tube. The tubes were shaken for $2 \mathrm{~h}$ at room temperature and centrifuged under the conditions of $11,000 \times g$ at $4^{\circ} \mathrm{C}$ for $20 \mathrm{~min}$. The supernatant was filtered using membrane filter (MCE type, Pore size $0.45 \mu \mathrm{m}$, ADVANTECMFS, Inc., Japan). Three hundred $\mu \mathrm{L}$ of the supernatant were de-proteinated with $900 \mu \mathrm{L}$ methanol. After the coagulation of protein, the samples were centrifuged again under the conditions of $16,000 \times g$ at $4^{\circ} \mathrm{C}$ for $3 \mathrm{~min}$ and diluted 100 folds for HPLC analysis.

The HPLC analysis was performed using Varian 920LC (Varian Medical Systems, USA) equipped with UVdetector, automatic injector, and dipeptide materials were separated with ZORBAX Eclipse Plus C-18 column ( $250 \mathrm{~mm} \times 4.5 \mathrm{~mm}, 5 \mu \mathrm{m}$, Aglient Technologies, USA), and carnosine was detected most precisely at $210 \mathrm{~nm}$. The mobile phase used isocratic HPLC method ( $5 \mathrm{mM}$ sodium 1-heptane-sulfonate, $\mathrm{pH} 2.3$, by $85 \%$ phosphoric acid with $\mathrm{MeOH}, 65 \%: 35 \%$, respectively). Column temperature was held at $30^{\circ} \mathrm{C}$, flow rate was $1 \mathrm{~mL} / \mathrm{min}$, and running time was $13 \mathrm{~min}$. The linear regression of standard was prepared using crystalline carnosine and anserine with distilled water in the range of 50 to $150 \mathrm{ppm}$. Detailed information for chemicals used for HPLC analysis was reported previously (Auh et al., 2010).

\section{Statistical analysis}

All data were analyzed by ANOVA according to a completely randomized design using the Proc Mixed procedure of SAS (SAS Inst., Inc., USA). Individual pig was an experimental unit. Outlier data were identified by the UNIVARIATE procedure of SAS, but no outliers were found. Least squares means were calculated and the means among treatments were compared by the PDIFF option with the Tukey's adjustment. Significance was set at $p<$ 0.05 .

\section{Results and Discussion}

All pigs remained healthy and easily consumed their respective diets throughout the experiment. There were no differences in body weight gain, feed intake, and feed efficiency during $56 \mathrm{~d}$ of the feeding trial (Data were not shown). For nutrient contents in pig muscles (Table 2), the concentrations of dry matter (DM), crude ash, and crude protein in the LD and VI were not different among dietary treatments. The concentrations of crude fat in the LD were less $(p<0.01)$ for $\mathrm{BM}$ and $\mathrm{BM}+\mathrm{Mg}$ treatment groups than for Basal treatment. The reason for this observation is likely associated with both a greater amount of crude protein in the diets containing blood meal than the basal diet and less energetic efficiency of crude protein for de novo lipogenesis in the body than other energy substrates such as carbohydrates and fats (Kil et al., 2013). However, the concentrations of crude fat in the VI did not differ among dietary treatments. Differences in the amounts of potential fat depositions between the LD and VI may be the reason for this observation.

Drip loss was less $(p<0.05)$ for $\mathrm{BM}+\mathrm{Mg}$ treatment than Basal treatment, whereas no significant differences were

Table 2. Effect of dietary supplementation of blood meal and additional Mg on the proximate analysis of longissimus dorsi (LD) and vastus intermedius (VI) in pigs

\begin{tabular}{|c|c|c|c|c|c|}
\hline \multirow{2}{*}{ Items } & \multicolumn{3}{|c|}{ Dietary treatments $^{\mathrm{a}}$} & \multirow{2}{*}{ SEM } & \multirow{2}{*}{$p$-value } \\
\hline & Basal & $\mathrm{BM}$ & $\mathrm{BM}+\mathrm{Mg}$ & & \\
\hline \multicolumn{6}{|c|}{ Longissimus dorsi (\%) } \\
\hline DM & 22.6 & 23.8 & 23.6 & 0.85 & 0.58 \\
\hline Crude ash & 0.99 & 0.99 & 0.99 & 0.02 & 0.99 \\
\hline Crude fat & $3.17^{\mathrm{x}}$ & $2.70^{y}$ & $2.63^{y}$ & 0.06 & $<0.01$ \\
\hline Crude protein & 24.0 & 24.3 & 24.0 & 0.61 & 0.93 \\
\hline \multicolumn{6}{|c|}{ Vastus intermedius (\%) } \\
\hline $\mathrm{DM}$ & 21.9 & 22.7 & 23.4 & 0.78 & 0.76 \\
\hline Crude ash & 0.99 & 0.99 & 0.99 & 0.03 & 1.00 \\
\hline Crude fat & 1.96 & 1.99 & 1.87 & 0.06 & 0.43 \\
\hline Crude protein & 22.7 & 22.9 & 22.8 & 0.24 & 0.84 \\
\hline
\end{tabular}

${ }^{\mathrm{x}, \mathrm{y}}$ Values in the same row with no common superscripts are different $(p<0.05)$

${ }^{\mathrm{a}}$ Basal, the basal diets; BM, 95.0\% Basal $+5.0 \%$ blood meal; BM+Mg, 94.8\% Basal +5.0 blood meal $+0.2 \% \mathrm{MgO}$ 
observed for BM treatment as compared to other 2 treatment groups (Table 3 ). This result is likely a consequence of high amounts of $\mathrm{Mg}$ in the diets containing blood meal and additional $\mathrm{Mg}$. It has been reported that inclusion of additional $\mathrm{Mg}$ in diets fed to growing-finishing pigs decreased drip loss in the pork, possibly due to the amelioration of stress responses in pigs (D'Souza et al., 1998; Kietzman and Jablonski, 1985). Although there was no significant difference, the drip loss was also reduced by $25.0 \%$ in BM treatment as compared to Basal treatment. This observation may be related with increased concentrations of carnosine in the LD as observed in this experiment and its antioxidant effects on the lipid membrane of muscle cells. Ma et al. (2010) reported that dietary supplementation of carnosine improved antioxidant capacity and decreased drip loss in the pork. However, in other measurements for determining pork quality, the $\mathrm{pH}$ and meat color (CIE $\mathrm{L}^{*}$, $a^{*}$, and $\left.b^{*}\right)$ in the LD were not influenced by dietary treatments.

The concentrations of carnosine in the LD were increased numerically by approximately $10.0 \%$ in both BM and $\mathrm{BM}+\mathrm{Mg}$ treatment groups than Basal treatment although we failed to detect the significance (Table 4). Similar results were also observed by the previous experiments using broiler chickens. Auh et al. (2010) and Park et al. (2013) reported that feeding the diets containing 5.0\% blood meal to broiler chickens increased the concentrations of carnosine in the breast meat. These results suggest that blood meal high in L-histidine can be a useful dietary ingredient in pig diets for producing the carnosine-enriched pork as observed in the chicken breast. However, the concentrations of anserine, a methylated form of carnosine, in the LD were not affected by dietary treatments. This result may be associated with little activity of carnosine methylation to anserine in pig muscles (Boldyrev and Severin, 1990). On the contrary, the concentrations of carnosine and anserine in the VI did not differ among dietary treatments. The reason for the differences in carnosine deposition between the LD and VI may be the fact that carnosine depositions are greater for white muscle type than for red muscle type and the LD contains a greater amount of white muscle fiber than the VI (Beecher et al., 1965; Plowman and Close, 1988).

Inclusion of additional $\mathrm{Mg}$ in the diets containing blood meal had no positive effects on carnosine and anserine depositions in the LD and VI. The Mg is a cofactor of carnosine synthetase (Kalyankar and Meister, 1959), and therefore, it is likely expected that dietary supplementation of additional $\mathrm{Mg}$ may promote carnosine synthesis in animal products (Park et al., 2013). However, the current ex-

Table 3. Effects of dietary supplementation of blood meal and additional Mg on drip loss, $\mathrm{pH}$, and meat color of longissimus dorsi (LD) in pigs

\begin{tabular}{|c|c|c|c|c|c|}
\hline \multirow{2}{*}{ Items } & \multicolumn{3}{|c|}{ Dietary treatments $^{\mathrm{a}}$} & \multirow{2}{*}{ SEM } & \multirow{2}{*}{$p$-value } \\
\hline & Basal & $\mathrm{BM}$ & $\mathrm{BM}+\mathrm{Mg}$ & & \\
\hline Drip loss, $\%$ & $2.8^{\mathrm{x}}$ & $2.1^{x y}$ & $1.7^{\mathrm{y}}$ & 0.29 & $<0.05$ \\
\hline $\mathrm{pH}$ & 5.74 & 5.77 & 5.75 & 0.02 & 0.62 \\
\hline \multicolumn{6}{|l|}{ Meat color ${ }^{b}$} \\
\hline CIE L* & 49.8 & 49.1 & 50.7 & 0.80 & 0.38 \\
\hline CIE $a^{*}$ & 4.7 & 5.1 & 5.8 & 0.42 & 0.19 \\
\hline CIE b* & 6.9 & 7.0 & 7.6 & 0.22 & 0.07 \\
\hline
\end{tabular}

${ }_{\mathrm{x}, \mathrm{y}}$ Values in the same row with no common superscripts are different $(p<0.05)$

${ }^{\mathrm{a}}$ Basal, the basal diets; $\mathrm{BM}, 95.0 \%$ Basal $+5.0 \%$ blood meal; $\mathrm{BM}+\mathrm{Mg}, 94.8 \%$ Basal +5.0 blood meal $+0.2 \% \mathrm{MgO}$

${ }^{\mathrm{b}} \mathrm{CIL} \mathrm{L}^{*}$ (lightness), black (0) to white (100) color scale; CIE a* (redness), red (+) to green (-) color scale; CIE b* (yellowness), yellow $(+)$ to blue $(-)$ color scale

Table 4. Effects of dietary supplementation of blood meal and additional Mg on carnosine and anserine concentrations of pig muscles

\begin{tabular}{|c|c|c|c|c|c|}
\hline \multirow{2}{*}{ Items } & \multicolumn{3}{|c|}{ Dietary treatments $^{\mathrm{a}}$} & \multirow{2}{*}{ SEM } & \multirow{2}{*}{$p$-value } \\
\hline & Basal & $\mathrm{BM}$ & $\mathrm{BM}+\mathrm{Mg}$ & & \\
\hline \multicolumn{6}{|c|}{ Longissimus dorsi (LD, mg/100g DM) } \\
\hline Carnosine & 312.7 & 347.5 & 348.2 & 14.90 & 0.19 \\
\hline Anserine & 10.8 & 11.8 & 16.2 & 2.69 & 0.36 \\
\hline \multicolumn{6}{|c|}{ Vastus intermedius (VI, mg/100g DM) } \\
\hline Carnosine & 291.3 & 306.3 & 296.3 & 15.47 & 0.79 \\
\hline Anserine & 15.8 & 16.0 & 18.2 & 1.26 & 0.37 \\
\hline
\end{tabular}

${ }^{\mathrm{a}}$ Basal, the basal diets; $\mathrm{BM}, 95.0 \%$ Basal $+5.0 \%$ blood meal; $\mathrm{BM}+\mathrm{Mg}, 94.8 \%$ Basal +5.0 blood meal $+0.2 \% \mathrm{MgO}$ 
periment and previous experiments using broiler chicken (Park et al., 2013) failed to find significant effects on the concentrations of carnosine in animal products. Therefore, it is most likely that inclusion of additional $\mathrm{Mg}$ in diets fed to animals may have no beneficial effects on carnosine synthesis in the animal body.

In conclusion, blood meal may be a potential ingredient in pig diets for enhancing carnosine concentrations in the pork. Inclusion of additional $\mathrm{Mg}$ in the diets containing blood meal decreases drip loss, but has no benefit on increasing concentrations of carnosine and anserine in the pork.

\section{Acknowledgements}

This work was carried out with the support of the Cooperative Research Program for Agriculture Science and Technology Development (ID: PJ009340), Rural Development Administration, Republic of Korea; and this research was also supported by the Chung-Ang University Excellent Student Scholarship in 2013.

\section{References}

1. Association of Official Analytical Chemists (AOAC). (1990) Official method of analysis. $14^{\text {th }}$ ed., AOAC, Washington, DC.

2. Aristoy, M. C. and Toldra, F. (2004) Histidine on tissue concentrations of histidine-containing dipeptides in adult cockerels. Meat Sci. 67, 211-217.

3. Auh, J. H., Namkung, N., Shin, K. S., Park, S. W., and Paik, I. K. (2010) Effect of supplementary blood meal on the content of carnosine and anserine in broiler meat. J. Poult. Sci. 47, 302-309.

4. Baker, K. M., Utterbrack, P. L., Parsons, C. M., and Stein, H. H. (2011) Nutritional value of soybean meal produced from conventional, high protein, or low-oligosaccharide varieties of soybeans and fed to broiler chicks. Poultry Sci. 90, 390-395.

5. Beecher, G. R., Cassens, R. G., Hoekstra, W. G., and Briskey, E. J. (1965) Red and white fiber content and associated post mortem properties of seven porcine muscles. J. Food. Sci. 30, 969-976.

6. Bogardus, S. L., and Boissonneault, G. A. (2000) Carnosine inhibits in vitro low-density lipoprotein oxidation. Nutr. Res.
20, 967-976.

7. Boldyrev, A. A. and Severin, S. E. (1990) The histidine-containing dipeptides, carnosine and anserine: distribution, properties and biological significance. Adv. Enzyme Regul. 30, 175-194.

8. D'Souza, D. N., Warner, R. D., Leury, B. J., and Dunshea, F. R. (1998) The effect of dietary magnesium asparate supplementation on pork quality. J. Anim. Sci. 76, 104-109.

9. Guiotto, A., Calderan, A., Ruzza, P., and Borin, G. (2005). Carnosine and carnosine-related antioxidants: a review. Curr. Med. Chem. 12, 2293-2315.

10. Honikel, K. O. (1998) Reference methods for the assessment of physical characteristics of meat. Meat Sci. 49, 447-457.

11. Kalyanker, G. D. and Meister, A. (1959). Enzymatic synthesis of carnosine and related beta-alanyl and gamma-aminobutyryl peptides. J. Biolol. Chem. 234, 3210-3218.

12. Kietzmann, M., and Jablonski, H. (1985). Blocking of stress in swine with magnesium aspartate hydrochloride. Parkt. Tierz. 661, 331-335.

13. Kil, D. Y., Kim, B. G., and Stein, H. H. (2013). Feed energy evaluation for growing pigs. Asian Australas. J. Anim. Sci. 26, 1205-1217.

14. Ma, X. Y., Jiang, Z. Y., Lin, Y. C., Zheng, C. T., and Zhou, G. L. (2010) Dietary supplementation with carnosine improves antioxidant capacity and meat quality of finishing pigs. Anim. Physiol. Anim. Nutr. 94, 286-295.

15. Nagasawa, T., Yonekura, T., Nishizawa, N., and Kitts, D. D. (2001) In vitro and in vivo inhibition of muscle lipid and protein oxidation by carnosine. Mol. Cell. Biochem. 255, 29-34.

16. Namgung, N., Shin, D. H., Park. S. W., and Paik, I. K. (2010) Effects of supplementary blood meal on carnosine content in the breast meat and laying performance of old hens. Asian Australas. J. Anim. Sci. 23, 946-951.

17. National Research Council (NRC) (1998) Nutrient Requirements of Swine. $9^{\text {th }}$ ed. National Academic Press, Washington, DC.

18. Park, S. W., Kim, C. H., Namgung, N., Jung, B. Y., Paik, I. K., and Kil, D. Y. (2013). Effects of dietary supplementation of histidine, $\beta$-alanine, magnesium oxide, and blood meal on carnosine and anserine concentrations of broiler breast meat. $J$. Poult. Sci. 50, 251-256.

19. Plowman, J. E., and Close, E. A. (1988) An evaluation of a method to differentiate the species of origin of meats on the basis of the contents of anserine, balenine, and carnosine in skeletal muscle. J. Sci. Food Agric. 45: 69-73.

(Received 2013.12.31/Revised 2014.3.6/Accepted 2014.2.18) 